\title{
Quasispecies pattern in coronavirus along with new concern of recurrence, relapse and re-infection of SARS-CoV-2
}

\author{
Pamayyagari Kalpana*
}

Department of Pharmacy Practice, Annamacharya College of Pharmacy, Rajampeta, Andhra Pradesh, India

\author{
Received: 10 June 2020 \\ Revised: 10 July 2020 \\ Accepted: 13 July 2020 \\ *Correspondence: \\ Dr. Pamayyagari Kalpana, \\ Email: pkalpana3366@gmail.com
}

Copyright: () the author(s), publisher and licensee Medip Academy. This is an open-access article distributed under the terms of the Creative Commons Attribution Non-Commercial License, which permits unrestricted non-commercial use, distribution, and reproduction in any medium, provided the original work is properly cited.

\begin{abstract}
Ever since the outbreak of pandemic novel corona virus (severe acute respiratory syndrome corona virus 2 (SARSCoV-2)), from December 2019, researchers worldwide are working round the clock to identify the drug targets and suitable treatment options. A better knowledge of virus diversification and evolution may be critical in preventing and treating the spread of such pathogenic viruses. This article reviews the evidences available regarding the genome sequence studies of severe acute respiratory syndrome corona virus (SARS-CoV), middle East respiratory syndrome corona virus and SARS-CoV-2 that support the quasispecies nature of virus. Further few concepts of reoccurrence, relapse and reinfection of corona virus were also summarized.
\end{abstract}

Keywords: COVID 19, Genome sequence, Novel corona virus, Quasispecies, Recurrence, Relapse, Re-infection

\section{INTRODUCTION}

Initially in February 2003, Severe acute respiratory syndrome (SARS) caused by severe acute respiratory syndrome corona virus (SARS-CoV) was first reported in Asia. This epidemic of SARS quickly affected 26 countries and more than 8,000 people fell ill and 774 died as per WHO. ${ }^{1}$ Almost after a decade of SARS outbreak, another viral respiratory disease known as middle east respiratory syndrome (MERS) caused by MERS coronavirus was first reported in Saudi Arabia in September 2012 and has spread to 27 countries. From its emergence through March 2020, WHO confirmed 2,553 MERS cases and 876 deaths. $^{2}$

Recently, in early December 2019, an outburst of pandemic corona virus disease (COVID-19) caused by severe acute respiratory syndrome corona virus 2 (SARSCoV-2) has been occurred. SARS-CoV-2 is a member of the family Coronaviridae, sub family Coronavirinae order Nidovirales and genera beta corona virus. It is a positive-sense, single-stranded enveloped RNA virus $(30 \mathrm{~Kb}$ genome) that is around $50-200 \mathrm{~nm}$ in diameter. Virus is encoded by structural protein the spike glycoprotein $(\mathrm{S})$ that consists of three $\mathrm{S} 1-\mathrm{S} 2$ heterodimers that bind to angiotensin-converting enzyme 2 (ACE2) receptor on type II pneumocyte. The other surface protein is the hemagglutinin-esterase (HE) dimer is as shown. ${ }^{3}$

\section{VIRAL QUASISPECIES}

Quasispecies theory was developed in the 1970's by Manfred Eigen and Peter Schuster to explain selforganization and adaptability of primitive replicons. This concept is applicable to any biological entities with less genetic size and high mutation rate. One such is the RNA viruses. ${ }^{4}$

Viral quasispecies refers to the viral RNA inhabitants consisting of mutant spectrum instead of genetic sequence 
with the same nucleotide. Mutant spectra are the source of virus adaptability as it is warehouse of genotypic and phenotypic viral variants. High mutation rates have impact on viral fitness and survival. Unrestricted replication results in fitness gain, with or without variation of the consensus sequence. In contrast, replication in the presence of mutagen results in accumulation of mutations that modify the consensus sequences, and decreased fitness. Thus, these highly inconsistent entities can quickly adapt to new environments and ecological changes, as evidenced by the emergence and reoccurrence of viral infections from animal reservoirs, including human immunodeficiency virus (HIV), SARS, influenza, Ebola, and dengue fever, among others. This complexity of mutant cloud can significantly affect disease progression and viral pathogenesis and response to treatment. ${ }^{5,6}$

\section{LITERATURE EVIDENCES RELATING NATURE OF QUASISPECIES TO CORONA VIRUSES}

\section{SARS and MERS}

During SARS outbreak in China, a study by $\mathrm{Xu}$ et al, provided data of genome sequencing results of 132 patients with SARS associated coronavirus from 19 individual hospitalized patients suggesting the typical characteristic of Quasispecies of SARS-CoV that is presence complex and dynamic distributions of mutants in vivo, rather than a single, defined genomic sequence. ${ }^{7}$ This can further be supported by another study at Hong Kong by Tang et al, they have reported data on a 386-nt deletion in SARS-CoV and their observation of both L386del variant and the wild-type variant in the same specimen raised the possibility that SARS-CoV exists as a Quasispecies. ${ }^{8}$

During MERS outbreak Briese et al conducted a study that demonstrated a model of interspecies transmission of MERS-CoV between camels and humans. The whole genome sequencing of MERS-CoV revealed the presence of sequence variants within the isolate from dromedary camels (DC) which indicated the existence of quasispecies present within the animal. But noticeably, no such sequences were identified in analysis on samples recovered from human cases (only clonal genomic sequences were reported). ${ }^{9}$

\section{Recent genome studies on novel corona virus (SARS- CoV-2)}

China: In the study conducted by $\mathrm{Wu}$ et al in a patient (worker at market) bedded in Central Hospital of Wuhan, China on December 2019. RNA sequencing of bronchoalveolar lavage sample from the patient found a new RNA virus strain formerly named as 'WH-Human 1' coronavirus (now COVID 19). Its genome sequence was 79 percent similar to the SARS-CoV, about 51.8 percent similar to the MERS-CoV, and about 87.6-87.7 percent similar to other SARS-like CoVs from Chinese horseshoe bats (called $\mathrm{ZC} 45$ and $\mathrm{ZXC} 21$ ) indicating the genesis from bats. It also confirms the existence of mutant gene variants that can be correlated to quasispecies nature of the virus. ${ }^{10}$

Italy: Genomic characterization of SARS-CoV-2 from the first case of COVID-19 in Italy by Capobianchi et al, suggests that the analysis of sequence variability supported the presence of viral quasispecies in the clinical sample as well as in the primary isolate. Two positions with variant frequency $>10 \%$ were observed in the sample. ${ }^{11}$

Nepal: In a study conducted by Sah et al a complete genomic study was done for SARS-CoV-2 strain obtained from an oropharyngeal swab specimen of a Nepalese patient with positive COVID-19. Full-genome comparison of the isolate revealed $>99.99 \%$ identity with two previously sequenced genomes available at GenBank for SARS-CoV-2 from Wuhan, China, and $>99.9 \%$ with seven additional sequences. ${ }^{12}$

\section{Recurrence, relapse re-infection of coronavirus}

Within no time the virus underwent a rapid dissemination and led to pandemic disaster worldwide. Recognizing the seriousness, many countries compelled for social distancing and lockdown to retard the spread of virus. Suspected subjects were isolated and testing was done. Positive SARS-COv-2 subjects stayed quarantine, and currently available supportive treatments were provided to cure patients. The recovery rate was promising to some extent and the many subjects with favorable test results were discharged. Unfortunately, some of the recovered cases were again testing positive implying chances of recurrence, relapse and re infection. It is most important to understand the basic differences of these terms.

\section{Terminologies}

Recurrence/reoccurrence: It is the fact of happening again (or) a new occurrence of something that happened lappeared before.

Relapse: Relapse may be defined as a recurrence with the same species and serologic strain of micro-organism that was present before therapy

Re-infection: Reinfection implies recurrence with distinct/ different micro-organism that caused the original infection.

So, to differentiate relapse and re infection, accurate serological testing is required to identify the exact strain of microorganism. However, both have a distinct dynamic mechanism to reoccur.

\section{Evidences of relapse and reinfection of SARS and MERS}

After the initial outbreak of SARS in 2003, no more SARS cases were reported since 30 April 2004. As per 
WHO records, to assess the risk of SARS reoccurrence and to prepare appropriate contingency plans, a document namely 'SARS risk assessment and preparedness framework October 2004' was framed by WHO. ${ }^{13}$

A retrospective analysis of experts opinions regarding the reoccurrence of SARS by Wong; majority experts agreed the recurrence of the epidemic but they were unlikely to predict whether reoccurrence as an epidemic or smaller outbreaks. ${ }^{14}$

However, two case reports were found regarding the relapse of SARS. Tsang et al reported a questionable case of SARS either as relapse or a hospital infection in 35 years old woman. The patient was suspected as possible relapse of SARS and was treated with combination of oral antivirals along with IV antibiotics. ${ }^{15}$ Another report by Chien et al narrated a case of 56 year old woman stating that recurrent relapses of SARS were closely associated with repeated attempts to taper the dose of corticosteroid. ${ }^{16}$

In 2007, a study conducted by Wu et al, provided a strong evidence that SARS-CoV antibodies are reduced $>3$ years after the symptom onset SARS and patients might be susceptible to reinfection $>3$ years after initial exposure. ${ }^{17}$

The data from one of the largest case series of nine patients from a tertiary care center in Saudi Arabia published by Alaskar et al, most of the cases had an active disease ( 1 case), relapse ( 2 cases) or refractory (5 cases) and 1 unknown case of MERS. Also, the two refractory cases had evidence of co infection with enterococcus and gram negative bacteremia. ${ }^{18}$

\section{Reoccurrence of novel corona virus SARS-CoV-2}

A recent study by Bao et al, investigated acquired immunity to SARS-CoV-2 in rhesus macaques. Four rhesus monkeys were infected with SARS-CoV-2 and two were reinfected after confirmed recovery. Upon reinfection, viral replication was not detected in nasopharyngeal or anal swabs, and reinfected monkeys did not show any signs of COVID-19 disease recurrence. This suggests that immunity acquired following primary infection with SARS-CoV-2 may protect from subsequent exposure to the virus. However, this might not exclude the concern of reinfection and further studies are required. 19

Further a case report of a 46 year old woman on recurrence of positive SARS-CoV-2 RNA in COVID-19 was narrated by Chena et al suggesting the reoccurrence of SARS-CoV-2 in convolascent patients. The report also highlights the need of both nasopharyngeal and oropharyngeal swabs test for SARS-CoV-2 RNA to reduce the false-negative rate. Patients in convalescence should also be regularly tested for infectivity assessment, and all the discharged patients should be home quarantined for at least 14 days. ${ }^{20}$
EVIDENCING SARS-COV-2 ON PARTICULATE MATTER: A POSSIBLE EARLY INDICATOR OF COVID-19 EPIDEMIC RECURRENCE

On 16 March, a position paper launched by the Italian Society of Environmental Medicine (SIMA) illustrated the possible link between the dramatic impact of COVID19 outbreak in Northern Italy and the high concentrations of particulate matter $\left(\mathrm{PM}_{10}\right.$ and $\left.\mathrm{PM}_{2.5}\right)$. Further SIMA suggested using this correlation worldwide as "indicator" of COVID-19 relapses. $^{21}$

\section{CONCLUSION}

Better understanding of virus nature is a key to tackle the virus spread and also provides clues to target and better treatment options. Relapse and re infection of COVID 19 is still questionable proper diagnostic methods are necessary to avoid false negative and to establish the recurrence.

\section{Funding: No funding sources \\ Conflict of interest: None declared \\ Ethical approval: Not required}

\section{REFERENCES}

1. World Health Organization, SARS (Severe Acute Respiratory Syndrome). Available at: https://www. who.int/ith/diseases/sars/en/. Accessed on 06 June 2020.

2. World Health Organization, Middle East respiratory syndrome coronavirus (MERS-CoV) - Saudi Arabia. Available at: https://www.who.int/csr/don/05-may2020-mers-saudi-arabia/en/. Accessed on 06 June 2020.

3. Kakodkar P, Kaka N, Baig MN. A Comprehensive Literature Review on the Clinical Presentation, and Management of the Pandemic Coronavirus Disease 2019 (COVID-19). Cures. 2020;12(4):e7560.

4. Domingo E, Perales C. Viral Quasispecies. PLOS Genetics. 2019;15(10):e1008271.

5. Martínez MA, Martrus G, Capel E, Parera M, Franco S, Nevot M. Quasispecies Dynamics of RNA Viruses. Viruses: Essential Agents of Life. 2012: 2142.

6. Domingo E, Sheldon J, Perales C. Viral Quasispecies evolution. Microbiol Mol Biol Rev. 2012;76(2):159216.

7. $\mathrm{Xu}$ D, Zhang Z, Wang FS. SARS-associated coronavirus Quasispecies in individual patients. N Engl J Med. 2004;350(13):1366-7.

8. Tang JW, Cheung JL, Chu IM, Sung JJ, Peiris M, Chan PK. The large 386-nt deletion in SARSassociated coronavirus: evidence for Quasispecies? J Infect Dis. 2006;194:808-13.

9. Briese T, Mishra N, Jain K, Zalmout IS, Jabado OJ, Karesh WB, Daszak P, et al Middle East respiratory syndrome coronavirus Quasispecies that include homologues of human isolates revealed through 
whole-genome analysis and virus cultured from dromedary camels in Saudi Arabia. mBio. 2014;5(3):e01146-14.

10. Wu F, Zhao S, Yu B, Chen YM, Wang W, Song ZG, et al. A new coronavirus associated with human respiratory disease in China. Nature. 2020;579(7798):265-9.

11. Capobianchi MR. Molecular characterization of SARS-CoV-2 from the first case of COVID-19 in Italy, Clinical Microbiology and Infection, Clin Microbiol Infect. 2020;26(7):954-6.

12. Ranjit Sah et al,Complete Genome Sequence of a 2019 Novel Coronavirus (SARS-CoV-2) Strain Isolated in Nepal. Microbiol Resource Announcements. 2020;9(11):e00169-20.

13. World health organization, WHO SARS Risk Assessment and Preparedness Framework October 2004. Available at: https://www.who.int/csr/ resources/publications/WHO_CDS_CSR_ARO_2004 2/en/. Accessed on 06 June 2020.

14. Wong TW. "Will the SARS epidemic recur?" A retrospective analysis of the experts' opinions. J Epidemiol Community Health. 2006;60(1):87.

15. Tsang OT, Chau TN, Choi KW, Tso EYK, Lim W, Chiu MC, et al. Severe acute respiratory syndrome: Relapse? Hospital infection?. Emerg Infect Dis. 2003;9(9):1180-1.

16. Chien JY, Hsueh PR, Chang SC, Hwang JJ, Yu CJ, Yang PC. Relapse of SARS upon tapering corticosteroid. Intensive Care Med. 2004;30(6):12401 .

17. Wu LP, Wang NC, Chang YH, Tian XY, Na DY, Zhang LY, et al. Duration of antibody responses after severe acute respiratory syndrome. Emerg Infect Dis. 2007;13(10):1562-4.

18. Alaskar A. Middle East Respiratory Syndrome (MERS) Infection in Hematological and Oncological Patients: A Case Series from a Tertiary Care Center in Saudi Arabia Blood. Outcomes Res-NonMalignant Conditions. 2019;134(1):5871.

19. Ota M. Will we see protection or reinfection in COVID-19?. Nat Rev Immunol. 2020.

20. Chen D, Xu W, Lei Z, Liu J, Gao Z, Peng L, et al. Recurrence of positive SARS-CoV-2 RNA in COVID-19: A case report. Int $J$ Infect Dis. 2020;93:297-9.

21. Setti L. Searching for SARS-COV-2 on Particulate Matter: A Possible Early Indicator of COVID-19 Epidemic Recurrence. Int $\mathrm{J}$ Environ Res Public Health. 2020;17(9):2986.

Cite this article as: Kalpana P. Quasispecies pattern in coronavirus along with new concern of recurrence, relapse and re-infection of SARS-CoV-2. Int J Basic Clin Pharmacol 2020;9:1310-3. 